Original Research Paper

\title{
Identification of Pests and Diseases on Anthurium Plants (Anthurium andraeanum) in Sewu Kembang Tourism Village, Karanganyar
}

\author{
Nur Rokhimah Hanik ${ }^{1} \&$ Rohmad Faoji ${ }^{*}$ \\ ${ }^{1}$ Biology Education Program, Faculty of Teacher Training and Education, University of Veteran Bangun \\ Nusantara, Sukoharjo, Indonesia
}

\begin{abstract}
Article History
Received : September 10 $0^{\text {th }}, 2021$

Revised : September 25 ${ }^{\text {th }}, 2021$

Accepted : October 05 $5^{\text {th }}, 2021$

Published : October $13^{\text {th }}, 2021$

*Corresponding Author:

Rohmad Faoji,

Biology Education Program,

Faculty of Teacher Training and

Education, University of Veteran

Bangun Nusantara, Sukoharjo,

Indonesia;

Email: rohmadf99@gmail.com
\end{abstract}

\begin{abstract}
Anthurium ornamental plants are currently very popular among ornamental plant lovers, both from the charm of the type and color and the high price. Although pests and diseases in anthurium are not very disturbing, if left unchecked it will greatly interfere with the beauty, inhibit growth and be detrimental to collectors and sellers/entrepreneurs of these ornamental plants. The purpose of this study was to determine the types of pests and diseases that attack anthurium plants. This research was carried out in the Sewu Kembang Nglurah Tourism Village, Tawangmangu Regency, Karanganyar Regency, for 30 days from Saturday, September 4 to October 3, 2021. This study used 20 samples of Anthurium plants. The tools used were cellphone cameras and stationery. The variables that will be observed are pests and diseases that attack Anthurium. This research used observation and interview methode, the data obtained were analyzed by qualitative descriptive. The results of this study found several pests and diseases on anthurium plants that caused the plant leaves and flowers to have holes, shriveled, yellowed spots, slimy, and caused stunted growth. The pests found were caterpillars and snails, while the diseases included fungus, chlorisis, leaf rust, anthracnose, curly leaves, and burnt leaves.
\end{abstract}

Keywords: Anthurium, Pests, Diseases and Sewu Kembang

\section{Pendahuluan}

Desa Nglurah, merupakan tempat wisata berupa agrowisata tanaman hias yang letaknya didekat lereng Gunung Lawu. Desa Nglurah (Kharisma, 2010). Ada berbagai macam tanaman hias yang dapat ditemuka di desa wisata ini antara lain: anthurium bunga, anthurium daun, adenium, aglonema, mawar, krisan, begonia, kaktus, anggrek dan masih banyak lagi.

Tanaman anthurium dikenal pula dengan nama Flamingo flower atau pigtail plant. Anthurium bunganya indah dan banyak dimanfaatkan sebagai tanaman hias dalam pot dan bunga potong. Bentuk bunga seperti hati, ada yang berwarna merah tua, merah muda dan putih. Merupakan bunga dari daerah sub tropis, umumnya dari Belanda, sehingga memerlukan syarat tumbuh pada suhu sekitar $23^{\circ} \mathrm{C}-29^{\circ} \mathrm{C}$, kelembapan tinggi dan membutuhkan naungan agar tidak terkena matahari langsung. Varietas - varietas yang berasal dari habitat asalnya memiliki bentuk dan warna bunga yang bervariasi (Endah H, 2001).

Menurut Badan Pusat Statistik pada tahun 2020, produksi tanaman anthurium bunga pada tahun 2020 mengalami penurunan menjadi sebanyak 2.505.198 tangkai dibanding pada tahun 2019 sebanyak 4.463. 472 tangkai (Badan Pusat Statistik, 2020). Persentase penurunan sebanyak 43,873\%.

Anthurium memiliki toleransi yang rendah terhadap organisme pengganggu tanaman (OPT) seperti hama dan penyakit. Apabila terdapat bagian tanaman yang terserang OPT maka nilai jual anthurium akan turun. Salah satu OPT yang sering menggangu tanaman anthurium adalah jamur Colletotrichum sp yang dapat menyebabkan 
penyakit antraknosa pada daun anthurium (Anthura, 2007).

Menurut David (2015), petani pemula dalam membudidayakan tanaman anthurium masih mengalami banyak kendala diantaranya adalah kendala teknik budidaya, kondisi fisiologis serta gangguan hama dan penyakit. Dari semua faktor tersebut yang sampai sekarang menjadi masalah adalah gangguan hama dan penyakit. Para petani anthurium biasa melakukan pendeteksian terhadap penyakit dengan melihat langsung kondisi tanaman yang terjangkit penyakit dan menanggulanginya secepat mungkin. Diketahui penyakit yang sering muncul pada tanaman hias ini adalah bercak daun, daun seperti kekuningan dan timbul bercak-bercak coklat. Namun karena pengetahuan yang terbatas, para petani pemula terkadang merasa kesulitan jika dihadapkan dengan beragam dan banyaknya jenis penyakit serta tidak tahu bagaimana cara mengatasinya.

Anthurium membutuhkan $25 \%$ cahaya matahari untuk berfotosintesis. Cahaya matahari berlebih hanya akan mengakibatkan daun terbakar sehingga menurunkan penampilannya. Suhu yang diperlukan pun umumnya sesuai suhu ruangan, berkisar antara 14-20 $\mathrm{C}$ dengan kelembaban 80-90\%. Bila terlalu lembab, anthurium lebih mudah terserang hama penyakit terutama pada bagian akar dan batang (Budhiprawira dan Lestari (2007). Kemudian Warnita et al. (2017) menyatakan media tanam anthurium terdiri atas tanah, pasir, dan pupuk kandang dicampur dengan perbandingan 1:1:1 (v/v).

Hama dan penyakit yang sering menyerang anthurium bunga adalah ulat, siput, cabuk dan jamur. Keempat pengganggu ini menyerang tanaman anthurium sepanjang tahun, tanpa bergantung musim. Pengendalian hama dan penyakit dilakukan dengan penyemprotan Fungisida Anvill dan Insektisida Thuricide serta Insektisida Buldok, yang dilakukan jika sudah ada tanda serangan berupa bercak coklat karena jamur, lubang di daun bekas serangan ulat dan siput. dan bunga yang berukuran tidak sempurna karena cabu (Hamidy, 2010).

Hama dan penyakit, tanaman bisa mengganggu pertumbuhan dan perkembangan tanaman. Ulat menyebabkan daun berlubang demikian pula dengan siput, hal ini dapat mengganggu proses fotosintesis dan jika dibiarkan terus - menerus menyebabkan tanaman merana (Hamidy, 2010).

Penyakit penting pada tanaman anthurium, antara lain adalah bercak daun dan bercak antraknosa. Bercak daun disebabkan oleh cendawan Cercospora anthurii (Mycosphaerella anthurii Miles). Gejala serangan penyakit ini adalah terjadinya bercak - bercak berwarna coklat dan dipusat bercak terbentuk konidium cendawan berbentuk gada memanjang atau benang yang lentur. Penyakit bercak antraknosa disebabkan oleh cendawan Collettotricum anthurii Del. Penyakit ini menyerang daun, tangkai daun dan bunga. Gejala serangannya adalah muncul bercakbercak coklat, berlakuk, dan tidak teratur (Rukmana, 1997).

Masalah serangan hama dan penyakit tanaman merupakan penghambat utama dalam meningkatkan produktivitas pertanian, mengurangi keindahan tanaman, serta mengganggu fisiologi atau pertumbuhan tanaman. Diagnosa penyakit pada tanaman biasanya dilakukan oleh seorang peneliti tanaman berdasarkan gejala yang diderita, penyakit ini bisa didapat dari gejala penyakit yang timbul (Raharjo, 2017).

Kendala teknik budidaya Anthurium adalah kondisi fisiologis serta gangguan hama dan penyakit. Dari semua faktor tersebut yang sampai sekarang menjadi masalah adalah gangguan hama dan penyakit (David. 2015). Banyak penelitian telah dilakukan dalam mengidentifikasi hama dan penyakit pada tanaman anthurium, namun penelitian ini masih sangat diperlukan karena di desa wisata tanaman hias Nglurah para petani dan penjual tanaman hias terutama anthurium masih memerlukan informasi tentang jenis hama dan penyakit yang menyerang anthurium untuk mengatasi dan meningkatkan produksi atau penghasilan.

Oleh karena itu dari banyaknya jenis hama dan penyakit yang menyerang tanaman anthurium menjadikan hal tersebut sebagai fokus utama objek kajian pada penelitian ini. Penelitian ini bertujuan dari penelitian ini untuk mengetahui serta mengidentifikasi secara jelas jenis hama dan penyakit yang menyerang tanaman anthurium. Selain itu dengan adanya penelitian ini diharapkan dapat menjadi bahan informasi 
bagi petani dan pedangan tanaman hias anthurium khusunya dan mampu membawa kebermanfaatan kepada masyarakat umum khususnya dalam menghadapi tantangantantangan dalam usaha budidaya tanaman anthurium.

\section{Bahan dan Metode}

\section{Waktu dan Tempat}

Kegiatan penelitian ini berlangsung selama 30 hari, mulai dilaksanakan pada tanggal 4 September sampai 3 Oktober 2021. Tempat penelitian ini dilaksanakan adalah di Desa Wisata Sewu Kembang Nglurah, Tawangmangu, Kabupaten Karanganyar.

\begin{abstract}
Alat dan Bahan
Alat yang digunakan dalam penelitian ini berupa kamera untuk mengambil gambar/ dokumentasi gejala yang nampak pada tanaman karena serangan hama dan penyakit, dan alat tulis serta tabel pengamatan untuk mencatat gejala yang tampak akibat serangan hama dan penyakit serta mencatat hasil wawancara. data. Bahan atau sampel yang digunakan dalam penelitian ini adalah tanaman anthurium sebanyak 20 sampel secara acak dari green house dan kios pedagang tanaman hias.
\end{abstract}

\section{Teknik pengumpulan data}

Pengumpulan data pada penelitian ini dengan menggunakan observasi dan wawancara. Tehnik pengumpulan data dilakukan melalui beberapa tahapan, diantaranya:

1. Menyiapkan peralatan yang akan digunakan dalam penelitian.

2. Mencari tanaman anthurium yang digunakan sebagai sampel atau objek kajian penelitian.

3. Mengamati dan mencatat jenis hama maupun penyakit yang terdapat pada tanaman anthurium.

4. Mengidentifikasi /mengamati gejala pada tanaman yang terkena hama maupun penyakit yang terdapat pada tanaman anthurium.

5. Mencocokkan gejala yang ditemukan dengan pustaka yang ada.

Kegiatan wawancara dilaksanakan dengan mencari sumber informasi kepada 3 responden yaitu, kepada pemilik tanaman dan 2 pegawai yang merawat tanaman dengan syarat mengerti jenis hama dan penyakit tanaman serta mengetahui cara mencegah dan mengatasi hama dan penyakit. Wawancara bertujuan untuk mencari serta memperkuat data tambahan yang diperoleh dari kegiatan observasi sebelumnya.

\section{Hasil dan Pembahasan}

Kegiatan penelitian identifikasi jenis hama dan penyakit pada tanaman anthurium didapatkan hasil berupa tabel dibawah ini.

Tabel 1. Hasil Observasi dan Identifikasi

\begin{tabular}{|c|c|c|c|c|c|}
\hline No & Sampel & Gejala & Hama & Penyakit & Gambar \\
\hline 1 & $\mathrm{~A} 1$ & $\begin{array}{l}\text { - Daun berlubang } \\
\text { - Daun bergerigi } \\
\text { pada bagian tepi } \\
\text { - Terdapat bekas } \\
\text { lendir }\end{array}$ & $\begin{array}{l}\text { Ulat dan } \\
\text { bekicot/ } \\
\text { siput }\end{array}$ & & \\
\hline 2 & A2 & $\begin{array}{l}\text { - Permukaan daun } \\
\text { bergelombang } \\
\text { - Daun terdapat } \\
\text { bintik abu-abu } \\
\text { - Daun pucat } \\
\text { - Daun hijau muda } \\
\text { - Daun lebih kecil }\end{array}$ & & $\begin{array}{l}\text { Kelainan } \\
\text { fisiologi } \\
\text { karena } \\
\text { defisiensi } \\
\text { nitrogen }\end{array}$ & \\
\hline
\end{tabular}


Hanik \& Faoji (2021). Jurnal Biologi Tropis, 21 (3): 993 - 1002

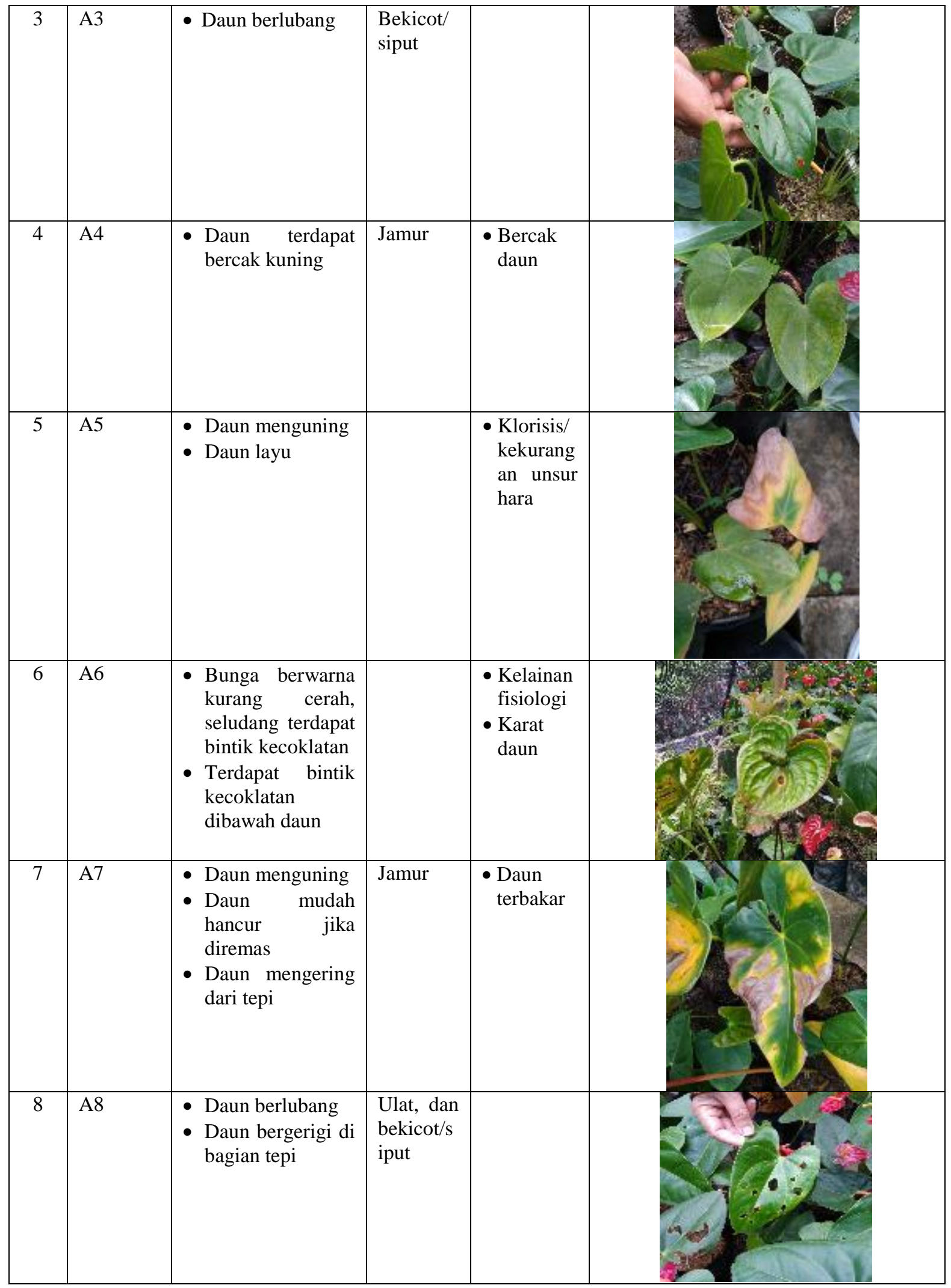


Hanik \& Faoji (2021). Jurnal Biologi Tropis, 21 (3): 993 - 1002

\begin{tabular}{|c|c|c|c|c|}
\hline 9 & A9 & $\begin{array}{l}\text { - Daun mengeriput } \\
\text { - Warna daun } \\
\text { pudar (gradasi) } \\
\text { - Permukaan daun } \\
\text { bergelombang }\end{array}$ & Jamur & $\begin{array}{l}\text { - Daun } \\
\text { keriting }\end{array}$ \\
\hline 10 & A10 & 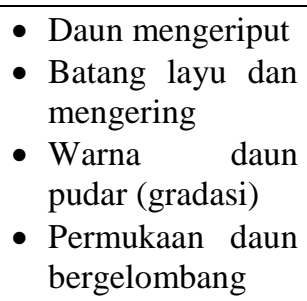 & Jamur & $\begin{array}{l}\text { - Daun } \\
\text { keriting }\end{array}$ \\
\hline 11 & A11 & $\begin{array}{l}\text { - Seludang terdapat } \\
\text { bintik keperakan }\end{array}$ & Thrips & \\
\hline 12 & A12 & $\begin{array}{l}\text { - Seludang } \\
\text { menguning }\end{array}$ & & $\begin{array}{l}\text { - Kelainan } \\
\text { fisiologi }\end{array}$ \\
\hline 13 & A13 & $\begin{array}{l}\text { - Daun hjau muda } \\
\text { - Daun } \\
\text { bergelombang }\end{array}$ & & $\begin{array}{l}\text { - Kelainan } \\
\text { fisiologi } \\
\text { karena } \\
\text { defisiensi } \\
\text { Nitrogen }\end{array}$ \\
\hline 14 & A14 & $\begin{array}{l}\text { - Daun pucat } \\
\text { - Daun menguning } \\
\text { - Daun layu }\end{array}$ & & - Klorisis \\
\hline 15 & A15 & - Daun menguning & & - Klorisis \\
\hline
\end{tabular}




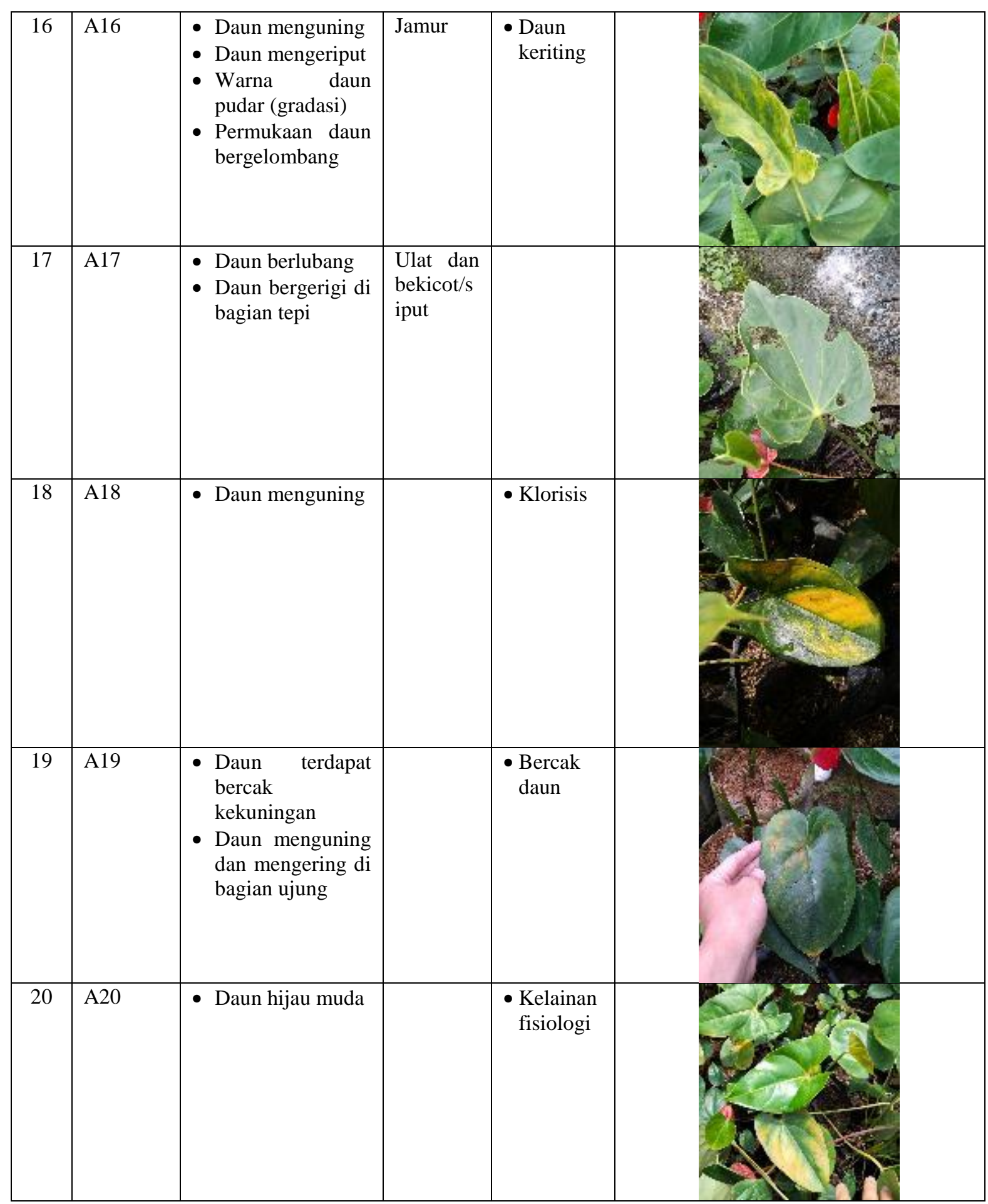

\section{Hama}

Hama tanaman yang pertama adalah ulat, yang merupakan penyebab daun menjadi berlubang dan bergerigi pada pinggirannya. Pengendalian hama ulat dapat dilakukan dengan menggunakan insektisida Thuricide yang merupakan insektisida hayati bekerja sebagai parasit larva ulat, dengan menggunakan Thuricide ini dirasa cukup efektif mengendalikan ulat, dosis yang digunakan yaitu 3 gram/ 14liter air (Hamidy, 2010). Menurut wawancara dari pemilik tanaman hama ulat dapat diatasi dengan cara manual, yaitu dengan diambil 
dan dibuang, tapi jika sudah terlalu banyak akan dilakukan dengan menggunakan insektisida. Dari data observasi yang didapatkan hama ini terdapat pada sampel A1, A8 dan A17.

Hama tanaman yang kedua adalah bekicot/siput. Hama ini juga menyebabkan daun menjadi berlubang. Hama ini dapat dikendalikan dengan cara manual, menurut pemilik tanaman hal ini lebih baik daripada penggunaan pestisida. Hal ini didukung juga dengan penelitian Hamidy, (2010) yang menyatakan bahwa siput hanya dikendalikan dengan manual yaitu dengan diambil dan dibuang cara ini dirasa lebih efektif dari pada dengan bahan kimia yang dapat merusak lingkungan. Menurut Tim Pengembang Budidaya Mutiara Air Laut (2010) hama ini memakan daun, terutama daun yang masih muda. Siput menyerang tanaman pada malam hari. Pengendalian dapat dilakukan dengan mengambilnya dan membuangnya. Jika serangan cukup banyak, pengendaliannya dilakukan dengan menyebar umpan beracun di tempat yang diperkirakan dilalui siput. Dari data observasi yang didapatkan hama ini terdapat pada sampel A1, A3, A8 dan A17.

Hama tanaman yang ketiga adalah jamur, ada berbagai jamur yang dapat menyebabkan penyakit pada anthurium antara lain hawar daun, bercak daun, antraknosa, daun keriting dan berbagai macam penyakit lainnya. Adanya jamur yang tumbuh pada anthurium dikarenakan kelembapan lebih dari 80\% (Astuti, 2007). Untuk mengatasinya dapat digunakan fungisida Anvil dengan dosis $3 \mathrm{cc}$ / 10liter air (Hamidy, 2010). Menurut pemilik tanaman lebih baik media tanam diganti, karena nutrisi dalam media sudah berkurang sehingga ketahanan terhadap OPT menjadi berkurang. Dari data observasi yang dilakukan hama ini terdapat pada sampel A4, A7, A9, A10 dan A16.

Hama tanaman yang keempat adalah thrips. Hama ini menyebabkan bercak keperakan pada batang, daun, bunga. Thrips / Dichromothrips smiti, Gejala serangan: Timbulnya bercak-bercak berwarna abu-abu keperakan pada daun, dapat juga menyerang pada bunga yang dapat mengakibatkan bunga tidak mekar dengan sempurna, akhirnya gugur (Boga, 2015). Dari data observasi yang dilakukan hama ini terdapat pada sampel A11.

\section{Penyakit}

Penyakit pertama yang dapat diidentifikasi adalah klorosis. Klorosis adalah penyakit yang ditandai dengan gejala daun menguning hampir keseluruhan dan daunnya layu. Menurut pemilik tanaman hal ini disebabkan karena terlalu banyak penyiraman sehingga mengakibatkan tidak sesuainya kelembapan dan suhu. Selain itu hal ini juga disebabkan pemberian pupuk yang berlebihan, kurangnya drainase sehingga air menggenang. Menurut Lakitan (2010) untuk tanaman cocok ternaung seperti anthurium, jika mendapatkan sinar matahari yang berlebih maka laju fotosintesis akan turun dan terjadi penguraian kloroplas mengakibatkan tanaman akan tumbuh kerdil dan cendrung menunjukkan gejala nekrosis dan klorosis. Menurut Putri (2000) bahwa pemberian pupuk pada tanaman anthurium sangat berpengaruh terhadap pertumbuhan tanaman tersebut. Jika tanaman kekurangan unsur hara maka metabolisme didalam tanaman tersebut akan terganggu yang berpengaruh terhadap pertumbuhan dan produksi tanaman seperti terganggunya pertumbuhan akar, batang dan daun. Tanaman akan menjadi kerdil dan muncul gejala-gejala visual seperti nekrosis dan klorosis. Demikian juga jika tanaman kekurangan cahaya maka proses fotosintesis akan terganggu, terutama penyerapan $\mathrm{CO}_{2}$ akan berkurang menyebabkan proses tofosintesis tidak optimal Untuk mengatasinya pemilik tanaman memindahkan tanaman ke media baru, selain itu memberikan pestisida dan fungisida supaya tidak mudah terkena penyakit karena tanaman dalam kondisi yang lemah sehingga ketahanan terhadap hama dan penyakit berkurang. Selain itu juga dilakukan pemotongan pada akar yang busuk. Dari data observasi yang didapatkan penyakit ini terdapat pada sampel A5, A14, A15 dan A18.

Penyakit kedua yang dapat diidentifikasi adalah karat daun. Penyakit karat daun ditandai dengan gejala bercak kuning atau coklat pada seluruh permukaan atas daun. Penyakit karat daun disebabkan karena kelembaban dan suhu yang tidak sesuai, penyiraman terlalu sering dan melimpah. Untuk penangannya, pemilik tanaman melakukan pengurangan penyiraman dan penggunaan fungisida. Dari data observasi yang didapatkan penyakit ini terdapat pada sampel A6.

Penyakit ketiga yang dapat diidentifikasi adalah daun terbakar. Penyakit daun terbakar ditandai dengan gejala daun terbakar tampak cokelat mengering, bila daun diremas mudah hancur, dan sebagian daun terbakar disertai 
kekuningan. Gejala-gejala diambil berdasarkan penelitian (Saputra et al, 2021). Untuk mengatasinya pemilik tanaman memindahkan tanaman ke daerah yang lebih teduh. Karena hal ini disebabkan daun menerima terlalu banyak sinar matahari sehingga menjadi terbakar. Dari data observasi yang didapatkan penyakit ini terdapat pada sampel A7.

Penyakit keempat yang dapat diidentifikasi adalah daun keriting. Penyakit daun keriting ditandai dengan gejala permukaan daun terasa bergelombang jika diraba, warna daun pudar (gradasi), daun mengeriput, dan warna semakin hijau muda. Gejala-gejala ini diambil berdasarkan penelitian (Saputra et al, 2021). Untuk mengatasi penyakit ini pemilik tanaman mengganti media tanam, menurutnya hal ini disebabkan karena media tanam yang sudah terlalu lama, sehingga kandungan unsur hara dalam media tersebut menjadi kurang. Karena kurangnya unsur yang dibutuhkan ketahanan tanaman berkurang dan menjadi mudah terkena hama dan penyakit. Dari data observasi yang didapatkan penyakit ini terdapat pada sampel A9, A10 dan A16.

Penyakit kelima yang dapat diidentidikasi adalah kelainan fisiologi karena kekurangan unsur tertentu. Dari data observasi yang didapatkan penyakit ini terdapat pada sampel A2, A6, A12, A13 dan A20. Menurut (Matana \& Mashud, 2015), gejala defisiensi $\mathrm{N}$ terlihat pertama kali pada daun-daun tua, yaitu daun berwarna hijau pucat, dan kemudian menjadi kuning pucat atau kuning cerah (klorosis) dan selanjutnya daun mengalami nekrosis. Kemudian berdasarkan Dinas Pangan, Pertanian dan Perikanan (2018) defiensi nitrogen memiliki gejala antara lain pertumbuhan tanaman berjalan lambat, tanaman kurus dan kerdil, daun hijau kekuningan, pendek, kecil dan tegak, daun yang sudah tua berwarna hijau muda, kemudian berubah kuning dan layu., bila sempat berbuah, buahnya akan kerdil, cepat masak lalu rontok. Untuk mengatasi defisensi N menurut (Tando, 2019), penanggulanagan terhadap kekurangan nitrogen dapat dilakukan dengan cara diberi pupuk yang mengandung nitrogen seperti pupuk kompos bisa juga dengan disemprotkan pada bagian daunnya.

Penyakit keenam yang dapat diientifikasi adalah bercak daun. Bercak daun ditandai dengan gejala daun terdapat bercak kuning atau cokelat.
Hal ini menyebabkan permukaan daun tertutup bercak dan mengurangi keindahan dari daun anthurium. Menurut Prajnanta (2008), pakar hama dan penyakit tanaman dari bayer cropscince, jika melihat gerjalanya kemungkinan besar bercak kuning disebabkan oleh nematoda atau penyakit lain seperti Fusarium. Sedangkan penyakit bercak daun juga menjadi momok bagi pekebun. Alasannya jika sekali terkena, kecantikan daun yang menjadi modal utama anthurium akan terganggu. Daun tampak kekuningan dengan bercak-bercak berwarna coklat. Jika dibiarkan lama-kelaman bercak berubah menjadi kehitaman. Bercak daun disebabkan oleh Pseudomonas cichorii dan Xanthomonas campestris. Kedua patogen ini masuk melalui luka di permukaan daun, bisa diatasi dengan aplikasi bakterisida seperti agrept konsentrasi 2,5 g/l, berbahan aktif tembaga seperti kocide 60 WDG konsentrasi $1 \mathrm{~g} / \mathrm{l}$, Cuprait konsentrasi 2,5 g/l. Penyemprotan dilakukan 1-2 kali seminggu. Daun yang terserang bercak kuning tidak dapat kembali berwarna hijau. Namun, daun berikutnya tumbuh sudah normal hijau. Dari data observasi yang didapatkan penyakit ini terdapat pada sampel A4 dan A19.

\section{Kesimpulan}

Berdasarkan penelitian yang telah dilakukan ditemukan beberapa hama pada tanaman anthurium yaitu hama ulat, bekicot/siput serta trips yang menyebabkan daun berlubang keriput dan bercak keperakan. Sedangkan penyakit yang ditemukan yaitu penyakit karena serangan jamur klorisis, karat daun, daun keriting, daun terbakar, kelaianan fisiologi dan bercak daun yang menyebabkan gangguan pada proses fisiologi sehingga pertumbuhannya terhambat. Masih diperlukan penelitian lanjutan dengan sampel yang lebih banyak untuk identifikasi hama dan penyakit pada tanaman hias anthurium.

\section{Ucapan Terimakasih}

Ucapan terima kasih kami sampaikan kepada bapak dan ibu dosen Program studi Pendidikan Biologi, Universitas Veteran Bangun Nusantara Sukoharjo yang telah memberikan banyak bantuan selama penelitian di desa Nglurah Tawangmangu, warga desa Nglurah 
Tawangmangu serta para mahasiswa yang telah membantu pelaksanaan penelitian dari awal hingga akhir.

\section{References}

Anthura (2007). Pot Anthurium Cultivation Guidelines. Bureau IMAC Bleiswijk B.V. Netherlands. 10h.

Astuti (2007). Kaya dari bisnis tanaman hias. AgroMedia Pustaka. Jakarta.

Badan Pusat Statistik (2020). Produksi Tanaman Florikultura (Hias) 2020. Indonesia. URL: https://www.bps.go.id/indicator/55/64/1/p roduksi-tanaman-florikultura-hias-.html (Accessed on September 18, 2021)

Boga, A. K. (2015). Potensi pengembangan Agribisnis bunga Anggrek di Kota Batu Jawa Timur. 2, 19-30.

Budhiprawira, S. \& D. Saraswati (2006). Anthurium. Penebar Swadaya. Jakarta.

Budhiprawira, S. \& Lestari G. (2007). Memperbanyak Anthurium Daun. Penebar Swadaya. Jakarta

David (2015). Diagnosa Penyakit Dan Identifikasi Jenis Tanaman Daun Anthurium Menggunakan Sistem Pakar. Seminar Nasional Informatika. 1 (1): 5560. URL: http://ejournal.potensiutama.ac.id/ojs/index.php/ SNIf/article/view/241

Dinas Pangan, Pertanian dan Perikanan (2018). Unsur Hara dan Kebutuhan Tanaman. Pontianak, Kalimantan Barat. Indonesia. URL:

https://pertanian.pontianakkota.go.id/artik el/52-unsur-hara-kebutuhan-tanaman.html (Accessed on September 17, 2021)

Endah H, Joesi (2001). Membuat Tanaman Hias Rajin Berbunga. Agromedia Pustaka Jakarta.

Hamidy (2010). Budidaya Anthurium Bunga Potong sp. Laporan Tugas Akhir (D III).
Agribisnis Hortikultura dan Arsitektur Pertamanan, Fakultas Pertanian Universitas Sebelas Maret. Surakarta URL:https://digilib.uns.ac.id/dokumen/de tail/15431/Budidaya-anthurium-bungapotong-sp (Accessed on September 12, 2021)

Junaedhie, K. (2006). Pesona Anthurium Daun. Agromedia Pustaka. Jakarta.

Kharisma, D. (2010). Agrowisata tanaman hias di desa Nglurah sebagai aset wisata kabupaten Karanganyar. Skripsi. Universitas Sebelas Maret, Surakarta, Jawa Tengah, Indonesia. URL: https://digilib.uns.ac.id/dokumen/detail/1 1198/Agrowisata-tanaman-hias-di-desaNglurah-sebagai-aset-wisata-kabupatenKaranganyar (Accessed on September 18, 2021)

Lakitan, B. (2013). Dasar-dasar Fisiologi Tumbuhan. PT. Raja Fartindo. Jakarta.

Matana, Y. R., \& Mashud, N. (2015). Respons Pemupukan N, P, K dan Mg Terhadap Kandungan Unsur Hara Tanah dan Daun pada Tanaman Muda Kelapa Sawit. B. Palma, 16(1), 23-31 DOI: http://dx.doi.org/10.21082/bp.v16n1.2015 $.23-31$

Prajnanta, F. (2008). Musuh-Musuh Anthurium. url:

https://embundaun.wordpress.com/2008/0 8/14/musuh-musuh-anthurium/ (Accessed on September 17, 2021)

Putri, D.A. (2000). Peningkatan Kualitas Anthurium hookeri dengan Pupuk Organik. Skripsi. Jurusan Agronomi Universitas Sebelas Maret, Surakarta, Jawa Tengah, Indonesia. URL: https://digilib.uns.ac.id/dokumen/detail/7 755/Peningkatan-kualitas-AnthuriumHookeri-melalui-pemberian-pupukorganik (Acessed on September 18, 2021)

Raharjo, A.A. (2017). Hama \& Penyakit Tanaman Kenali \& Atasi. PT. Trubus Swadaya. Jakarta 
Rukmana, Rahamat (1997). Anthurium. Kanisius. Yogyakarta.

Saputra, A.C., Parhusip, J., \& Yusuf, H. (2021). Rancang Bangun Sistem Pendeteksian Penyakit Tanaman Anthurium Dengan Metode Variable-Centered Intellegent Rule System (VCIRS). Journal of Information Technology and Computer Science, 1(1): 39-46. DOI:

10.47111/jointecoms.v1i1.2542

Tando, E. (2019). Upaya Efisiensi Dan Peningkatan Ketersediaan Nitrogen Dalam Tanah Serta Serapan Nitrogen Pada Tanaman Padi Sawah (Oryza sativa L.). Buana Sains, 18(2), 171. DOI: https://doi.org/10.33366/bs.v18i2.1190
Tim Pengembang Budidaya Mutiara Air Laut. (2010). Budidaya Anthurium Daun di Lahan. Sumber Belajar. URL: https://sumberbelajar.belajar.kemdikbud.g o.id/sumberbelajar/tampil/Budidaya-

Anthurium-Daun-di-Lahan--2010/

(Accessed on September 18, 2021)

Warnita, N., \& Akhir, Vina (2017). Growth Response of Two Varieties Chrysanthemum (Chrysanthemum sp.) on Some Media Composition. International Journal on Advanced Science, Engineering and Information Technology, 7(3), 928-935.

DOI: 